\title{
EVOLUTION AND MODERN TENDENCIES IN THE THEORY OF LEADERSHIP
}

\author{
Yurii Safonov ${ }^{1}$ \\ Kyiv National Economic University named after Vadym Hetman, Ukraine \\ Yevgen Maslennikov ${ }^{2}$, Nataliia Lenska ${ }^{3}$ \\ Odesa I.I. Mechnikov National University, Ukraine
}

\begin{abstract}
Leadership as a social phenomenon accompanies mankind throughout its existence. In different historical epochs, attempts were made to study leadership qualities on the basis of a description of the personalities of great people. As a result, the idea of leadership quickly evolved as the accumulation of theoretical and empirical material, revealing new facets of this complex phenomenon. In foreign social sciences, the theory of leadership has developed in several directions and by now a number of complementary theories and concepts have been developed, which predetermines the need to describe their continuity and development. For this reason, the purpose of the paper is to analyse the basic theories and concepts of leadership, as a sociopsychological phenomenon, the most significant in the context of studying the formation of the leader as an organizational leader. Methodology. The methodological and informational basis of the investigation is scientific articles, materials of periodicals, resources of the Internet. To achieve the goal set, the following general scientific and special methods were used: morphological analysis, system and structural-logical analysis, formalization, analogy, comparison and integration, tabular method. Results. As a result of the research, a brief historical overview of approaches to the study of leadership was given; the logical continuity of the basic concepts and methods of research was considered; the main current trends in leadership research in recent years were revealed. Practical implications. In order to realize the leadership potential, it is necessary to know what determines leadership, on what it depends. Thus, the problem of studying the phenomenon of leadership in a modern organization is relevant; the considered theories of leadership can be applied by managers depending on the level of economic development of the organization. Value/originality. The authors identified current trends in the theory of leadership and possibilities of their further development.
\end{abstract}

Key words: management, leadership, theories of leadership, leadership style, transformational leadership, transactional leadership, behavioural approach, situational approach, charisma, emotional intelligence.

JEL Classification: B20, M12

\section{Introduction}

Leadership is a special type of attitude towards a person, based on the recognition of his abilities to manage and those human qualities that are so necessary for the modern leader. Leadership is built on the voluntary recognition of a person's ability to understand the interests of other people and to manage them in accordance with these interests.

In the past, leadership was seen as a set of innate traits or as features of a style of behaviour. Most definitions of leadership include three components: influence, group, and purpose. Firstly, leaders are people who influence the behaviour of others. Secondly, leadership is usually investigated in the context of groups, especially working groups. Third, the leadership study focuses on the group goal, which must be achieved. Thus, the following definition of leadership can be given: it is a process, in which a person influences other members of a group to achieve the goals of a group or organization. The true leader, capable of leading people with him, is one who acquires universal recognition among people.

\footnotetext{
Corresponding author:

${ }^{1}$ Department of Macroeconomics and Public Administration, Kyiv National Economic University named after Vadym Hetman.

E-mail: sum1971@ukr.net

${ }^{2}$ Department of Economics and Management, Odesa I.I. Mechnikov National University.

E-mail: evgenmaslennikov@ukr.net

${ }^{3}$ Department of Economics and Management, Odesa I.I. Mechnikov National University.

E-mail: nlenskaya96@mail.ru
} 
The history ofleadership research dates back to ancient times. Scientists of antiquity and ancient China tried to systematize and describe the qualities inherent in the leader, unfortunately, not mastering modern scientific methodology. However, over the past centuries, the situation has changed dramatically; the scientific approach has taken the lead. More and more theories appeared, corresponding to the paradigm prevailing at one time or another. At first, it was a personal approach, from where the theory of leadership features emerged, then behaviourism took over the dominant position and then a behavioural approach emerged in leadership psychology. Further, authentic theories of leadership were created on the one hand, and attempts were made to integrate opposing approaches on the other.

Each of these approaches has scientific leadership concepts that explain this phenomenon. Let us consider the most popular of them.

\section{Evolution of the theory of features}

The great man theory. This group of concepts is a prescientific, philosophical doctrine of leadership. Various philosophers (Lao-Tzu, Confucius, Homer, Aristotle, Plato, Niccolo Machiavelli) tried to design an image of an ideal governor on the basis of notional conclusions (Oganyan, 2006). They did not use the scientific method and, obviously, they did not apply the approved psychodiagnostic techniques. In this regard, the understanding of the same feature could differ from one author to another, and lists of leadership features often contradicted each other. It is important that leadership was considered only at the level of large groups. The basic postulate of "The Great Man" theory was that it is impossible to become a leader, they can only be born.

Time passed, scientific methods of researching the personality appeared. However, this postulate remained in force. The founder of the scientific approach was F. Galton, who believed that the leading role in human behaviour, including the leader, is played by hereditary factors. The development of this idea could be seen in the works of sociologists, social psychologists and philosophers (F.A. Woods, J.G. Tarde, F. Nietzsche). A. Wiggam argued that the reproduction of leaders depends on the level of fertility among the ruling classes (Wiggam, 1931). Finally, S. Klubeck and B. Bass discovered that people who are not inclined to leadership by nature can hardly be made leaders, except to try to influence them with psychotherapy (Klubeck, 1954).

The trait theory of leadership. Soon serious concepts of personal traits and, respectively, the questionnaires, which allowed defining them, began to appear. Here, first of all, it is necessary to mark out R. Cattell who in 1954 have compared leaders to other members of the group; the first were ahead of the last on eight merits of the personality: moral maturity $(\mathrm{C})$; domination $(\mathrm{E})$; integrity of character $(\mathrm{G})$; social courage $(\mathrm{N})$; insight $(\mathrm{N})$; independence of harmful inclinations (O); will power (Q3); lack of excessive experiences (Q4) (Daft, 2006).

Thus, the era of allocation of leadership skills where each researcher studied the leader's figure from a position of own concept of personal traits and own questionnaire has come. Among the most modern, the concept of personal qualities "The Big Five" by Warren Norman is considered to be the most recognized.

The great man theory has not reached a dead end. It got a new birth in the theory of charismatic leadership. Representatives of the theory of charisma insisted on one, but integral quality, which makes a person a leader - charisma. Charisma according to Max Weber is the quality bestowed by God. He put charismatic power in opposition to traditional and rational power. An important difference between the theory of charisma and the trait theory is the difference in the origin of leadership power. In Weber's concept, charismatic power is a magical quality bestowed from above. However, already in this concept, one can see hints of scientific understanding. So, M. Weber insisted that in order for the followers to recognize the leader's qualities in a leader, he must clearly argue his demands, prove his own skills, and demonstrate that subordination to him leads to certain results (Friedland, 1964).

Transformational leadership. Transformational leadership is a modern embodiment of the theory of charisma. The term "transformational leadership" has been introduced by J.V. Downton (1973) for the first time. However, this concept has already received the development at James MacGregor Burns. He understands transformational leadership as a process, in which the leader and the follower, interacting definitely, lift each other to the higher level of motivation and personal/moral development. Leaders appeal to the highest ideals and values and also accept and realize these values in practice (Bensman, Givant, 1975).

Bernard Bass, Burns's follower, investigated leadership in the context of how a transformationalleader influences followers. Transformational leadership includes four main components: charisma and idealized influence; inspiring motivation; intellectual stimulation; individual approach (Avolio, Bass, 1988). Various emotions and feelings are inherent in the behaviour of the leader. In particular, for the inspiring motivation process, enthusiasm, optimism, and excitement are inherent; for idealized influence - determination, confidence and pride; for intellectual stimulation - hostility, challenge, and anger; for an individual approach - sympathy, care, and love (Connelly, 2002).

The theory of emotional intelligence and primary leadership. The important role of emotions in the process of transformational leadership made scientists pay attention to the concept of emotional intelligence (Fig. 1). A clear awareness of his mental processes 
and, in particular, the emotional state, is required from the leader. The theory of emotional intelligence by J.D. Mayer and P. Salovey, in the aftermath developed by D. Goleman and R. Boyatzis, most clearly describes the figure of the leader in this vein.

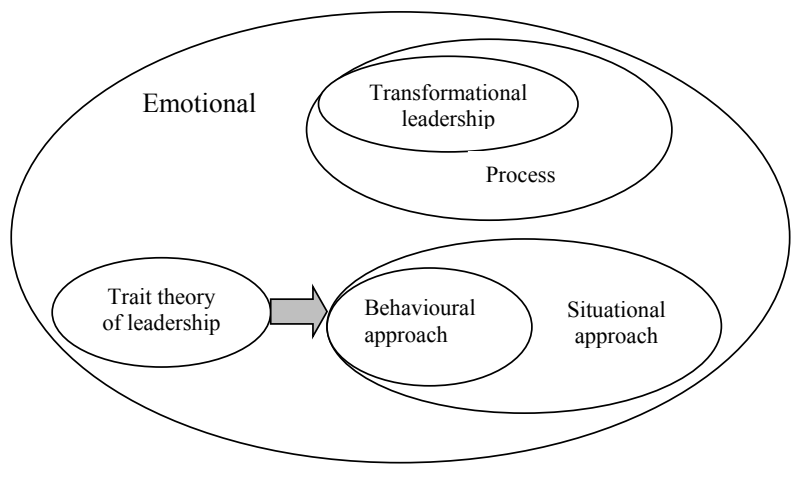

Fig. 1. The theory of emotional leadership as a synthesis of different approaches (Goleman, 2012)

The emotional brain (the limbic system) is responsible, both for the demonstration of our emotions and for our memory. When memorizing, the hippocampus connects this or that sensory information with the emotional state, and when similar sensory information is subsequently presented, the emotional reaction is already recorded. On these processes, for example, human intuition and the phenomenon of bad apprehension are based. However, emotional intelligence is more than an emotional brain. So, D. Goleman singles out the following components of emotional intelligence: knowledge of oneself and one's emotions; the ability to control oneself and one's feelings; the ability to understand the feelings and desires of others; the ability to control the feelings and desires of others. These qualities indicate the need to use the complete work of the brain and its logical part, even more so. Leaders either spontaneously experience the emotions that they show to their followers, or they easily create and demonstrate the appropriate emotions. In other words, leaders control their feelings. Followers react positively to positive emotions; there is an increase in sympathy for the leader (Brotheridge, 2006). The influence of the emotions of transformational leaders on the emotions and affective reactions of followers can be explained by emotional contamination (Newcombe, Ashkanasy, 2002).

\section{Evolution of the behavioural trend in leadership researches}

Leadership style theories. Behavioural theories of leadership appeared simultaneously with the occupation by behaviourism of a leading position in scientific psychology. The basic "stimulus-response" behaviourism formula also found an application in the theory of leadership. It was assumed that we can get the desired behaviour if we correctly select the stimulus that this behaviour can cause. The idea arose that there is a certain behavioural style that will make it possible to achieve the greatest results. The most popular researches in this vein were made by Kurt Lewin and Ralph White. They investigated the influence of three styles of leadership (liberal, authoritative, democratic) on the performance of the group (Table 1). It turned out that

Table 1

Classification of leadership styles by K. Lewin (supplemented by the authors)

\begin{tabular}{|l|l|l|l|}
\hline \multicolumn{1}{|c|}{$\begin{array}{c}\text { Interaction } \\
\text { Parameters }\end{array}$} & \multicolumn{1}{|c|}{ Authoritative } & \multicolumn{1}{c|}{ Democratic } & \multicolumn{1}{c|}{ Liberal } \\
\cline { 2 - 4 } Methods of decision-making & Resolves all issues individually & $\begin{array}{l}\text { Consults with the subordinates } \\
\text { before making a decision }\end{array}$ & $\begin{array}{l}\text { Waits for the directions from above } \\
\text { or decisions of the meeting }\end{array}$ \\
\hline $\begin{array}{l}\text { Ways of bringing solutions to } \\
\text { the performer }\end{array}$ & Orders, controls, commands & Offers, argues, affects & Asks, persuades \\
\hline Allocation of responsibility & Takes or passes to subordinates & $\begin{array}{l}\text { Allocates responsibility, delegates } \\
\text { authorities }\end{array}$ & Tries to shift off any responsibility \\
\hline Attitude to the initiative & Completely suppresses & $\begin{array}{l}\text { Encourages, uses in the interests } \\
\text { of the matter }\end{array}$ & Gives to subordinates \\
\hline Attitude to the recruitment & $\begin{array}{l}\text { Does not accept or gets rid of } \\
\text { skilled workers }\end{array}$ & $\begin{array}{l}\text { Selects business, competent } \\
\text { workers }\end{array}$ & Is not in charge of selection \\
\hline Style of communication & $\begin{array}{l}\text { Keeps distance, is not } \\
\text { communicative }\end{array}$ & $\begin{array}{l}\text { Is friendly, enjoys } \\
\text { communication }\end{array}$ & $\begin{array}{l}\text { Comes into contact with } \\
\text { subordinates only on their initiative }\end{array}$ \\
\hline $\begin{array}{l}\text { Nature of relations with the } \\
\text { subordinates }\end{array}$ & Hard, dictated by the mood & $\begin{array}{l}\text { Smooth manner of } \\
\text { communication, constant self- } \\
\text { control }\end{array}$ & Gentle, flexible \\
\hline Attitude to the discipline & $\begin{array}{l}\text { An adherent of formal discipline, } \\
\text { strict schedule }\end{array}$ & $\begin{array}{l}\text { A supporter of a reasonable } \\
\text { discipline, has differentiated } \\
\text { attitude to people }\end{array}$ & $\begin{array}{l}\text { Does not require respect for formal } \\
\text { discipline, patient to contraventions }\end{array}$ \\
\hline $\begin{array}{l}\text { Choice of the method of } \\
\text { influence on subordinates }\end{array}$ & $\begin{array}{l}\text { Regards punishment as the main } \\
\text { method of stimulation, rarely } \\
\text { encourages the elected }\end{array}$ & $\begin{array}{l}\text { Uses various methods of } \\
\text { encouragement and punishment }\end{array}$ & Uses reward more often \\
\hline
\end{tabular}


the authoritative style led to the greatest productivity but the relations in the group and the creativity of its participants suffered. With the democratic style, the opposite situation was observed. Liberal style showed the worst results in all parameters. The classification of $K$. Lewin became the basis for the creation of many new models of leadership. However, they all came down to finding intermediate options (for example, authoritativeliberal, authoritative-democratic leadership styles).

Later, based on this concept, Robert Blake and Jane Mouton proposed their "Managerial Grid" (Fig. 2) (Blake, Mouton, 1992). In their model, they claim that there is the most effective style that combines both the orientation to the result and the orientation to the relationship. This style was called team leadership.

It is worth saying that the ideal style of leadership was not found. Different styles of leadership turned out to be effective in different situations, as K. Lewin himself said.

Motivational theories. Motivational theory by R. Howe, B. Base understands leadership as an attempt to change the behaviour of members of the group through a change in their motivation. Abraham Maslow claimed that leadership arises in the process of transforming the desires of people into motives that depend on the environment. This idea was concretized by J. LipmanBlumen in the concept of connective leadership, according to which the modern leader should be able to establish connections between his motives and goals, as well as the goals and motivations of other people. Hence the emergence of many humanistic theories that considered the conflict between the motivations of the individual and the goals of the social structure, into which he enters. It is necessary to build an organization in such a way that it does not suppress the individual and, at the same time, is effective.

Transactional leadership. Transactional leadership was born from behavioural theories of exchange. They, in turn, are based on the theory of operant conditioning by B.F. Skinner and assume that any interaction of people is an exchange where everyone bears the benefits and costs. The first transactional theorist to talk about leadership was Peter Blau. He pointed out that leadership shows in a situation of nonequilibrium exchange. In the case when the individual has nothing to repay, he provides himself with a generalized loan. If this option is implemented purposefully, we are talking about the phenomenon of leadership. However, the theory of transactional leadership was developed in detail by E. Hollander. He understands leadership as an exchange between a leader and followers. The leader provides followers with benefits in the form of: organizing actions; clarification of the situation; coordination of efforts; attention. Followers also reward the leader with: recognition; respect; the adoption of influence (Hollander, 2009).

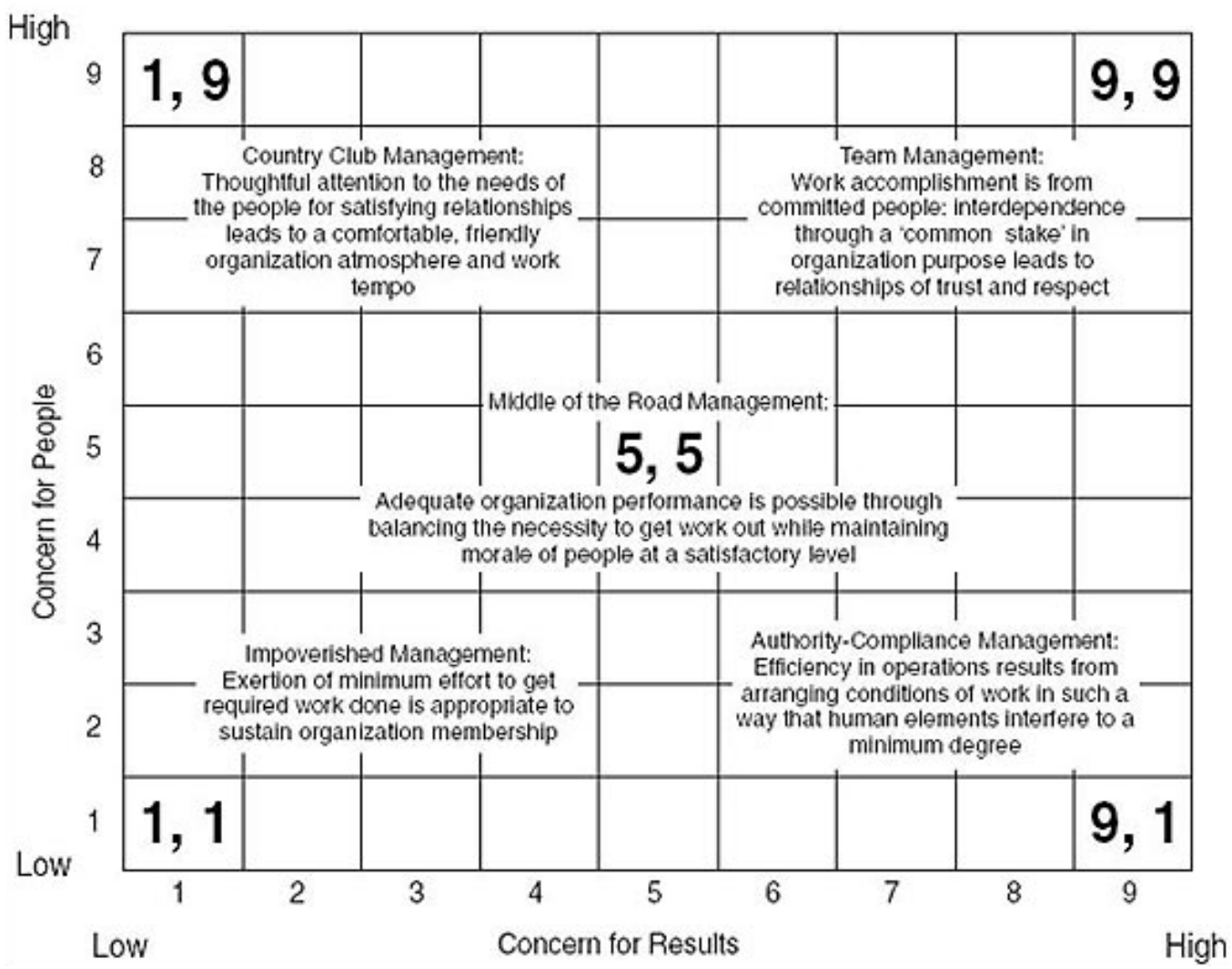

Fig. 2. Blake-Mouton Managerial Grid 


\section{Evolution of the situational approach in leadership}

Situational theories. These theories deny the personality in the course of leadership and direct all attention to a situation. So, Herbert Spencer specifies that it is not the person who changes time, but time creates great people (Spencer, 1841). Also, the theory of situational leadership by R. Stogdill notes that the same person can become a leader in one situation and cannot in another. The theory of "leadership substitutes" by S. Kerr and J. Jermier assumes that presence of the leader isn't a necessary condition of productivity of group as the absence of the leader can be compensated by parameters of the situation (Pochebut, Chiker, 2000).

Personal and situational theories. Here at the same time both psychological traits of the leader and a condition, in which there is a leadership process, are considered. So, according to K. Keyes, leadership is a result of three factors: personal traits; features of the group and its members; group problem. A.S. Kaze also says that leadership is generated by three factors: personal qualities of the leader, group, and situation. And, for example, the main idea of the concept of "the distributed leadership" consists that in a group it is not obligatory to have one leader. At each stage of implementation of the project by the interim leader, there is a carrier of the competence, which is the most demanded at present.

Situational-behavioural theories. This direction is a combination of a situational and behavioural approach. Here, the leadership behavioural styles that are effective in a given situation are determined. The first supporters of this direction in 1958 were Tannenbaum and Schmidt, who pointed out that the leadership style (authoritative or democratic) can be effective depending on three variables: the characteristics of the leader, the characteristics of the group, and situational factors (Fig. 3) (Tannenbaum, 1961). However, the most popular theory was Fred Fiedler's theory, who distinguished three situational variables: relations, task structure and powers (Fig. 4). Efficiency is achieved

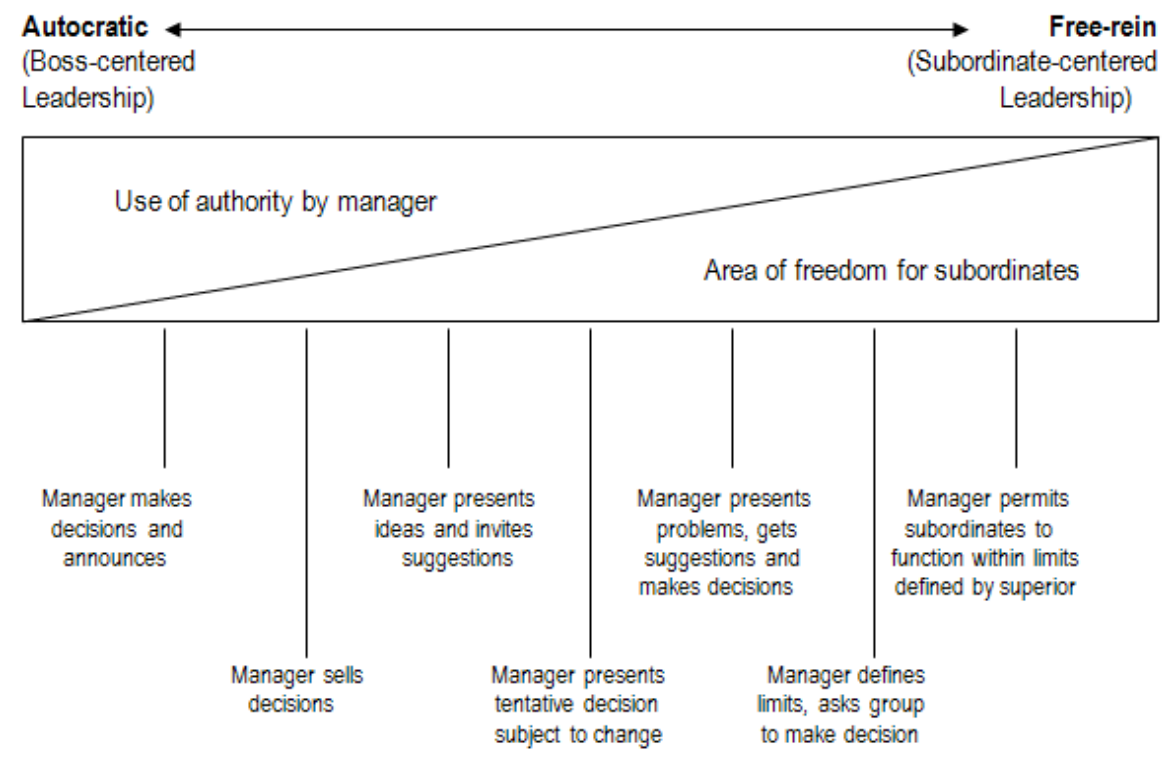

Fig. 3. The Tannenbaum-Schmidt Leadership Continuum

\begin{tabular}{|c|c|c|c|c|c|c|c|c|}
\hline \multirow[b]{2}{*}{ Leader-Member Relations } & \multicolumn{8}{|c|}{ Leadership Situations } \\
\hline & Good & Good & Good & Good & Poor & Poor & Poor & Poor \\
\hline Task Structure & High & High & Low & Low & High & High & Low & Low \\
\hline Position Power & Strong & Weak & Strong & Weak & Strong & Weak & Strong & Weak \\
\hline Favorableness of Situation & \multicolumn{3}{|c|}{ Most Favorable } & \multicolumn{3}{|c|}{ Moderate Favorable } & \multicolumn{2}{|c|}{ Least Favorable } \\
\hline Appropriate Leader Behavior & \multicolumn{3}{|c|}{ Task-Oriented } & \multicolumn{3}{|c|}{ Relationship-Oriented } & \multicolumn{2}{|c|}{ Task-Oriented } \\
\hline
\end{tabular}

Fig. 4. Fiedler's Contingency Model 


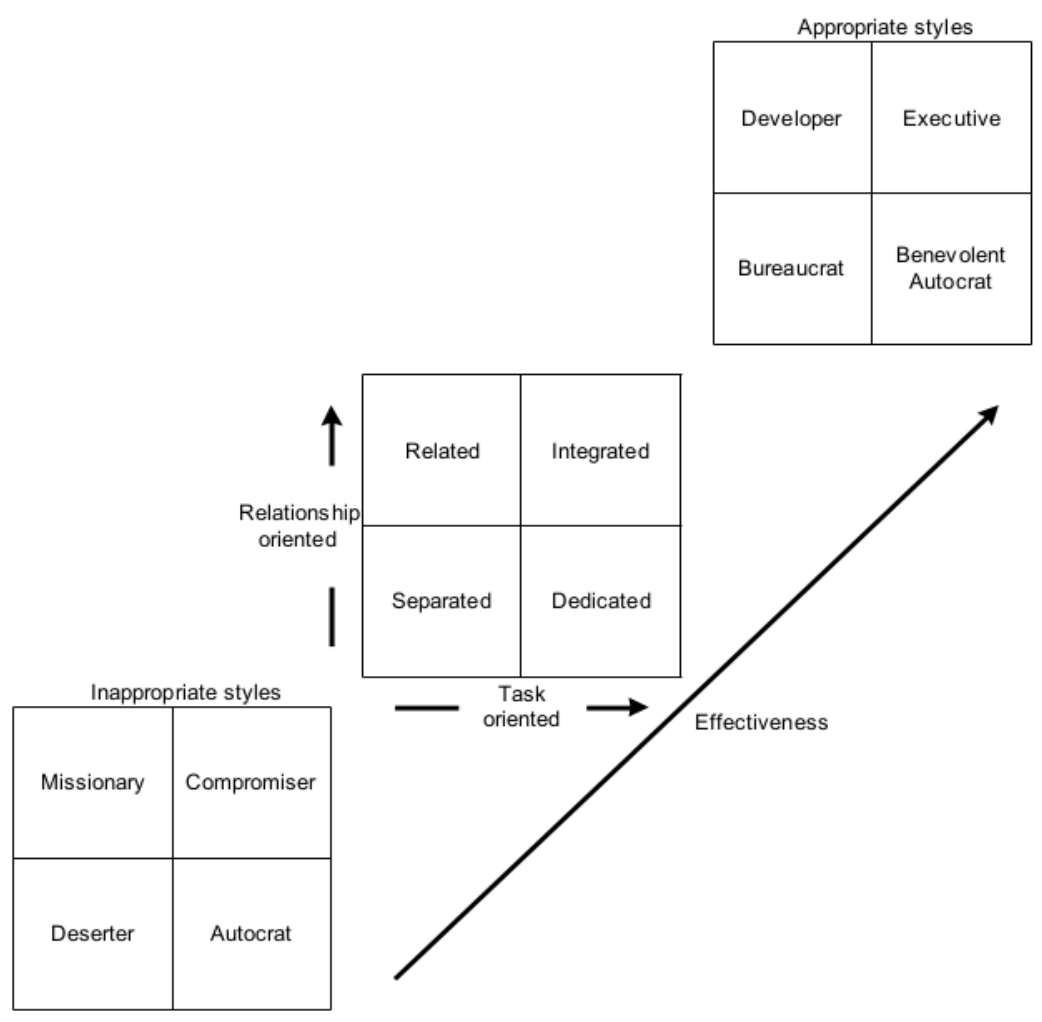

Fig. 5. The Three-Dimensional Model by W. Reddin

if, in the least and most favourable situations leaders implement a work-oriented style, and in the neutral situations - a relationship-oriented style (Fiedler, 1967). Gradually, the number of variables increased and W. Reddin proposed a three-dimensional model, in which there were 12 cells and whose third dimension was efficiency, that is, the manager's ability to achieve the goal set (Fig. 5) (Reddin, 1970).

\section{Modern trends in the development of the theory of leadership}

The elements of each of the described above leadership theories are still used today. However, the transition to a new paradigm led to the emergence of fresh ideas. Understanding of the world as a "dynamic, ever-changing, risky and complex" creates new concepts of leadership. From this perspective, creating conditions for change is a key aspect of leadership (Maxwell, 2006). It should be noted that, in previous theories, little attention has been paid to this issue.

At the beginning of the XXI century, special meaning is given to the ways of introducing changes that allow adapting to environmental conditions. To adapt to a chaotic world, leaders create learning organizations, in which each employee is involved in the process of identifying and solving problems so that the organization can grow and develop. Instead of leading and controlling, leaders create the image of the future and form a corporate culture that is conducive to the implementation of a forward-looking concept. At the same time, the hierarchical structure is destroyed and the organization becomes a community of people with the same goals and interests.

\section{Conclusions}

Tracing the logic of the development of the leadership theories, it can be noted that they all started from one-factor approaches, that initially one factor was considered as the determinant of the leadership: personal qualities, behavioural style, situational characteristics. Understanding the shortcomings of a one-way approach, leadership models began to be combined, two-factor concepts emerged: personal-situational, behaviouralsituational, personality-behavioural theories. However, this was not enough. The final stage in the study of leadership was the systematic approach, which included many factors. For example, the theory of emotional intelligence takes into account the personality traits of the individual, and his behaviour, and the situation in which it is realized.

Thus, it is possible to make a conclusion that a leader who wants to work as efficiently as possible, cannot afford to apply just one style of leadership throughout his career. The leader must rather learn to use all styles, methods, and types of influence that are most appropriate for a particular situation. 


\section{References:}

Blake, R., Mouton, J. (1992). Nauchnyie metodyi rukovodstva. - Kyiv, Nauk. dumka, 234 p.

Daft, R.L. (2006). Uroki liderstva: per. s angl. - Moskva, Eksmo, 408 p.

Goleman, D. (2012). Emotsionalnoe liderstvo: Iskusstvo upravleniya lyudmi na osnove emotsionalnogo intellekta: per. s angl. - Moskva, Alpina Pablisher, $301 \mathrm{p}$.

Maxwell, J.S. (2006). Liderstvo: 25 klyuchevyih printsipov postroeniya vzaimootnosheniy s lyudmi: per s angl. Minsk, Popurri, $366 \mathrm{p}$.

Oganyan, N.N. (2006). Tri epohi gosudarstva i vlasti. Platon, Makiavelli, Stalin. - Moskva, Grifon, 190 p.

Pochebut, L.G., Chiker, V.A. (2000). Organizatsionnaya sotsialnaya psihologiya. - Saint Petersburg, Rech, 298 p. Avolio, B.J., Bass, B.M. (1988). Transformational leadership, charisma and beyond. - Lexington, Lexington Books, $470 \mathrm{p}$.

Bensman, J., Givant, M. (1975). Charisma and modernity: the use and abuse of a concept. - Social research, № 4(42), p. 32-33.

Brotheridge, C.M. (2006). A review of emotional labour and its nomological network: practical and research implications. - Ergonomia IJE\&HF, № 28, p. 295-309.

Connelly, S. (2002). A closer look at the role of emotions in charismatic and transformational leadership. - St. Louis, $\mathrm{MO}$, Elsevier, 259 p.

Fiedler, F.E. (1967). A Theory of Leadership Effectiveness. - New York, McGraw-Hill, 303 p.

Friedland, W. (1964). For a sociological concept of charisma. - Social forces, № 43(112), p. 107-109.

Hollander, E.P. (2009). Inclusive Leadership: The Essential Leader-Follower Relationship. - New York, Routledge, $263 \mathrm{p}$.

Klubeck, C., Bass, B. (1954). Differential Effects of Training on Persons of Different Leadership Status. - Human Relations, № 7, p. 59-72.

Newcombe, M.J., Ashkanasy, N.M. (2002). The role of affect and affective congruence in perceptions of leaders: An experimental study. - Leadership Quarterly, № 13, p. 601-614.

Reddin, W. (1970). Managerial Effectiveness. - New York, McGraw-Hill, 345 p.

Spencer, H. (1841). The Study of Sociology. - New York, D. A. Appleton, 152 p.

Tannenbaum, R. (1961). Leadership and Organization. A Behavioural Science Approach. - New York, McGrawHill, 474 p.

Wiggam, A.E. (1931). The Biology of Leadership. - New York, Pitman, 371 p. 